\title{
Analisis Faktor-Faktor Yang Mempengaruhi Minat Beli Konsumen Dalam Membeli Rumah Di Kota Batam
}

\author{
Nora Pitri Nainggolan ${ }^{1}$, Heryenzus ${ }^{2} *$ \\ Universitas Putera Batam \\ Jl. Letjen R Soeprapto Muka Kuning, Batam 29433, Kepri \\ *email; heryenzuss@gmail.com
}

\begin{tabular}{|c|c|}
\hline Artikel Info & ABSTRAK \\
\hline $\begin{array}{c}\text { Received: } \\
6 \text { Maret } 2018 \\
\text { Revised: } \\
18 \text { Maret 2018, } \\
\text { Accepted: } \\
\text { 10 April } 2018\end{array}$ & $\begin{array}{l}\text { Tujuan penelitian ini adalah untuk mengetahui apakah faktor Kualitas Produk, } \\
\text { Harga,Lokasi, Promosi mempengaruhi minat beli dalam membeli rumah di kota Batam. } \\
\text { Penelitian ini menggunakan analisis regresi linier berganda dengan program SPSS Versi } \\
\text { 20. Populasi yang digunakan adalah masyarakat Kota Batam. Sedangkan sampel yang } \\
\text { digunakan sebanyak } 399 \text { orang dengan metode proportional sampling. Hasil } \\
\text { menunjukkan bahwa pengaruh kualitas produk terhadap minat beli konsumen dalam }\end{array}$ \\
\hline & $\begin{array}{l}\text { membeli rumah di Kota batam berpengaruh signifikan. Pengaruh harga terhadap minat } \\
\text { beli konsumen dalam membeli rumah di Kota Batam berpengaruh signifikan. Pengaruh } \\
\text { lokasi secara parsial terhadap minat beli konsumen dalam membeli rumah di Kota } \\
\text { Batam berpengaruh signifikan. Pengaruh promosi secara parsial terhadap minat beli } \\
\text { konsumen dalam membeli rumah di Kota Batam berpengaruh signifikan. Dan adanya } \\
\text { pengaruh signifikan kualitas produk, harga, lokasi, promosi secara simultan terhadap } \\
\text { minat beli konsumen dalam membeli rumah di Kota Batam. }\end{array}$ \\
\hline
\end{tabular}

Kata Kunci: Kualitas Produk, Harga, Lokasi, Promosi, Minat Beli

\section{Analysis of Factors that influence consumer purchasing power in buying a house in Batam City}

\begin{abstract}
The purpose of this study is to determine whether the factors that can be used for the purchase of houses in the city of Batam. This study uses multiple linear regression analysis with SPSS Version 20 program. Population which is society of Batam City. The sample used is 399 people with proportional sampling method. The results show that the quality of products to buy consumers in buying a house in the City of batamuling significant. The influence of prices on consumers in buying a home in Batam City is significant. The partial influence of location on consumer interest in buying a house in Batam City is significant. The effect of partial promotion on consumer interest in buying a house in Batam City has a significant effect. And requirements have a significant effect on product quality, price, location, promotion to consumer purchase in buying house in Batam City.
\end{abstract}

Keywords: Product Quality, Price, Location, Promotion, Buying Interest

How to Cite:

Nainggolan, N. P., \& Heryenzus. Analisis Faktor-Faktor Yang Mempengaruhi Minat Beli Konsumen Dalam Membeli Rumah Di Kota Batam. Jurnal Ilmiah Manajemen dan Bisnis, 19(1),41-54 https://doi.org/10.30596/jimb.v19i1.1772. 


\section{JURNAL ILMIAH MANAJEMEN dan BISNIS}

\section{PENDAHULUAN}

Pertumbuhan investasi di Indonesia mengalami kemajuan yang sangat pesat. Aliran investasi asing atau foreign direct investment ke Indonesia semakin meningkat. Salah satu booming investasi yang terjadi di Indonesia adalah di sektor properti. Perkembangan sektor properti di Indonesia yang kian melonjak membuat para investor lokal maupun asing berlomba untuk menginvestasikan dana mereka di bidang jasa pengembangan ini. Tidak mengherankan jika kemudian banyak bermunculan perusahaan baru yang menamai diri mereka sebagai perusahaan pengembang atau yang disebut dengan developer. Perkembangan usaha developer juga sangat meningkat tajam di Kota Batam.

Berdasarkan data sensus penduduk dari Badan Pusat Statistik jumlah penduduk di Kepulauan Riau sebanyak 2.028.169 jiwa dan sebanyak 1.236.399 berada di kota Batam Berdasarkan data dari situs resmi Persatuan Pengusaha Real Estate Indonesia, di Kepulauan Riau sendiri tepatnya di kota Batam, permintaan akan properti berupa rumah, rumah perkantoran (rukan) dan rumah toko (ruko) terus meningkat dari tahun ke tahun. Lonjakan pertumbuhan penduduk di kota Batam terus meningkat mencapai $4.95 \%$ setiap tahunnya. Hal ini diakibatkan oleh faktor kelahiran setiap tahun ditambah lagi dengan banyaknya transmigran yang mencoba peruntungannya di kota ini, menjadi salah satu penyebab tingginya pertumbuhan penduduk dan berakibat pada meningkatnya permintaan masyarakat untuk memiliki rumah.

Konsumen adalah hal yang menjadi tujuan utama pada sebuah perusahaan jasa. Dalam hal ini seperti yang telah disebutkan diatas jasa yang akan dibahas oleh peneliti adalah developer. Perusahaan developer yang ada di kota Batam saat ini sangat berkembang pesat diantaranya Cipta Group, PT Batam Riau Bertuah, PT Adhya Bumi
Batam, PKP Developer \& Real Estate, PT Fanindo Cipta Propertindo, PT Batam Park, Mitra Raya Group, PT Latrade Batam Indonesia, PT Batam Bumi Sugiraya, PT Total Garaha Insani, PT Citra Perdana Cemerlang. Bahkan tiga Developer besar di Indonesia juga telah memasuki kota Batam yaitu Ciputra Group, Agung Podomoro Land dan Sinar Mas Land.

Saat ini semua produsen memahami begitu pentingnya peranan dan arti kualitas produk yang unggul untuk memenuhi harapan pelanggan pada semua aspek produk yang dijual ke pasar. Dengan kualitas yang bagus dan terpercaya, maka produk akan senantiasa tertanam dibenak konsumen, persepsi konsumen terhadap kualitas produk akan membentuk preferensi dan sikap yang pada gilirannya akan mempengaruhi minat beli konsumen tersebut. (Widyasari dan Fifilia, 2009)

Sebuah perusahaan harus mampu mengenal dan mengetahui apa yang menjadi kebutuhan dan keinginan konsumen. Perusahaan juga harus selalu mencari informasi mengenai apa yang diharapkan konsumen dari suatu produk. Dengan tujuan agar perusahaan dapat selalu menciptakan produk yang sesuai dengan keinginan calon konsumen. Poin penting bagi sebuah perusahaan untuk dapat memenangkan suatu persaingan pasar, yaitu perusahaan tersebut perlu memperhatikan apa yang melandasi seorang konsumen dalam memilih suatu produk, dalam hal ini adalah minat membeli dari seorang konsumen yang selalu timbul setelah adanya proses evaluasi alternatif. Kota Batam dengan tingkat penduduk yang tinggi memiliki keragaman ekonomi penduduk, dimana banyak penduduk yang memiliki ekonomi yang tinggi namun banyak juga yang memiliki ekonomi menengah kebawah. Oleh sebab itu dikarenakan pendapatan sangat mempengaruhi daya beli, maka diharapkan para pengusaha developer dapat 
menghadirkan rumah hunian dengan harga yang relevan dengan kebutuhan penduduk di kota Batam. Dengan hadirnya developer yang mampu menawarkan harga yang beragam hal ini dapat meningkatkan minat beli masyarakat di kota Batam untuk membeli dan memiliki hunian dengan harga bersaing. (Firdaus, 2017)

Lokasi juga menjadi faktor penting lainnya yang sangat mempengaruhi minat beli seorang konsumen. Lokasi rumah yang diinginkan oleh konsumen biasanya terletak di lokasi yang strategis, dekat dengan tempat kerja, pusat perbelanjaan, dekat dengan rumah ibadah dan bagi keluarga yang telah memiliki anak jarak antara rumah dan tempat sekolah anak juga menjadi hal yang perlu dipertimbangkan. Oleh karena itu pihak developer diharapkan mampu memenuhi keinginan-keinginan konsumen tersebut agar para konsumen tertarik untuk membeli rumah yang ditawarkan.

Kegiatan promosi yang menarik juga tak dapat dipungkiri mampu menarik minat beli konsumen. Banyak para developer yang menawarkan harga down payment yang rendah dan dapat dicicil, menawarkan bunga KPR yang rendah, pemberian subsidi, kemudahan bertransaksi, juga memberikan hadiah doorprize tertentu untuk menarik minat konsumen. (Nasution dan Yasin, 2014)

Berdasarkan fenomena yang terjadi masih terdapat beberapa kekecewaan konsumen terhadap kualitas rumah yang ditawarkan, dimana masih sering terdapat kerusakan bangunan rumah sebelum ditempati, proses komplain kerusakan yang berkepanjangan, pembuatan saluran air yang tidak benar dapat mengakibatkan banjir pada saat hujan, atap yang sering bocor karena genteng yang tidak berkualitas. Hal-hal tersebut apabila dirasakan oleh konsumen maka akan menurunkan minat beli konsumen tersebut terhadap rumah lainnya yang dibuat oleh developer tersebut dan apabila kejadian ini diceritakan kepada rekan atau saudara maka akan mempengaruhi persepsi konumen lain sebelum membeli rumah dan mampu mengurungkan minat belinya terhadap rumah yang ditawarkan developer tersebut. (Eri et al., 2011). Permasalahan mengenai harga rumah juga sering menjadi keresahan masyarakat. Masih banyaknya rumah yang berada di lokasi yang tidak strategis dengan harga yang tinggi yang sulit terjangkau oleh konsumen. Pembangunan rumah juga tidak lagi memperhatikan letak strategis, masih banyak letak perumahan yang tidak terjangkau oleh transportasi umum, jauh dari tempet kerja dan jauh dari pusat perbelanjaan. Promosi yang diberikan pada awal menarik konsumen, sering tidak sesuai dengan realisasi, adanya syarat-syarat yang harus dipenuhi sebelum mendapatkan promosi tersebut.

Menurut Kotler dan Keller, (2010) kualitas didefinisikan sebagai "'keseluruhan ciri serta sifat barang dan jasa yang berpengaruh pada kemampuan memenuhi kebutuhan yang dinyatakan maupun yang tersirat"'. Sedangkan Menurut Kotler dan Armstrong, (2008) definisi kualitas produk adalah " "the ability of a product to perform its functions, it includes the product's overall durability, reliability, precision, ease of operation and repair, and other valued attributes"," yang artinya kemampuan sebuah produk dalam memperagakan fungsinya, hal itu termasuk keseluruhan durabilitas, reliabilitas, ketepatan, kemudahan pengoperasian dan reparasi produk juga atribut produk lainnya.

Gitosudarmo, (2008) mengemukakan bahwa harga adalah sejumlah uang yang dibutuhkan untuk mendapatkan sejumlah barang beserta jasa-jasa tertentu atau kombinasi dari keduanya. Sebelum harga itu ditetapkan, terlebih dahulu manajer harus menetapkan tujuan penetapan harga tersebut, lebih lanjut Adapun tujuan penetapan harga menurut Gitosudarmo, 
(2008) yaitu mencapai target pengembalian investasi atau tingkat penjualan netto suatu perusahaan, memaksimalkan profit, Alat persaingan terutama untuk perusahaan sejenis, Menyeimbangkan harga itu sendiri, sebagai penentu market share, karena dengan harga tertentu dapat diperkirakan kenaikan atau penurunan penjualannya.

Kemudian Rangkuti, (2011) mengemukakan indikator harga adalah (1) Penilaian mengenai harga secara keseluruhan, harga yang telah ditetapkan oleh perusahaan dapat dianalisa dengan melihat tanggapan yang diberikan konsumen terhadap harga tersebut, apakah konsumen telah menerima harga yang ditetapkan dengan manfaat yang diterima. (2) Respons terhadap kenaikan harga, jika terjadi kenaikan harga dari suatu produk, sebaiknya dilihat bagaimana respon konsumen terhadap kenaikan harga tersebut, apakah akan mempengaruhi keputusan dalam membeli produk tersebut ataukah sebaliknya. (3) Harga produk tertentu dibandingkan produk yang sama apabila ditempat lain. Konsumen dalam menentukan produk yang akan dibeli, akan membandingkan harga tersebut harga produk di tempat lain kebanyakan perusahaan dalam menawarkan produknya menetapkan harga berdasarkan suatu kombinasibarang secara fisik ditambah beberapa jasa lain serta keuntungan yang memuaskan.

Promosi merupakan salah satu kegiatan pemasaran yang penting bagi perusahaan dalam upaya mempertahankan kontinuitas serta meningkatkan kualitas penjualan. (Swastha, 2009) menyatakan bahwa promosi dipandang sebagai kegiatan komunikasi pembeli dan penjual dan merupakan kegiatan yang membantu dalam pengambilan keputusan di bidang pemasaran serta mengarahkan dan menyadarkan semua pihak untuk berbuat lebih baik. Tjiptono, (2008) mendefinisikan promosi sebagai "'aktivitas pemasaran yang berusaha menye bar informasi, mempe-ngaruhi/ membujuk, dan atau mengingatkan pasar sasaran atas perusahaan agar bersedia menerima, membeli dan loyal pada model perumahan yang ditawarkan perusahaan yang bersangkutan"". Menurut (Kotler dan Keller, 2010) indikator promosi adalah (1). Memberitahu, tujuan ini bersifat informasi di mana produsen menggunakan promosi untuk memberitahukan pasar, apa yang ditawarkan olehnya. Promosi ini sering digunakan pada tahap-tahap awal siklus kehidupan produk. Informasi ini juga membantu konsumen dalam menentukan jenis perumahan yang akan . dibelinya, (2). Membujuk, tujuan ini bersifat persuasif di mana perusahaan berusaha memberikan kesan positif terhadap pembeli. Maksudnya agar dapat memberi pengaruh dalam waktu yang lama terhadap perilaku pembeli. Promosi yang bersifat persuasive ini digunakan memasuki tahap pertumbuhan dalam siklus kehidupannya. (3) Mengingatakan, tujuannya untuk mempertahankan pembeli dengan terus mengingatkan adanya jenis perumahan tersebut. Promosi yang bersifat mengingatkan ini terutama diperlukan untuk jenis perumahan yang telah memasuki tahap kedewasaan dalam siklus kehidupan.

Lokasi menurut Lupiyoadi, (2013) merupakan suatu tempat dimana hasil produk perusahaan berada. Lokasi akan ikut berperan dalam menentukan kesuksesan suatu usaha karena lokasi akan berpengaruh terhadap besarnya pasar potensial yang dapat dicapai oleh suatu perusahaan. Menurut Tjiptono, (2008) pemilihan tempat atau lokasi ini perlu mempertimbangkan berbagai faktor berikut, misalnya (a) Akses, misalnya lokasi yang mudah dijangkau soleh sarana transportasi umum dan (b) Visibilitas, yaitu lokasi yang dapat terlihat dengan jelas dan berada di tepi jalan.

Minat beli (willingness to buy) merupakan bagian dari komponen perilaku dalam sikap mengkonsumsi. Menurut Kotler dan Keller, (2009) minat beli adalah perilaku konsumen yang muncul sebagai 


\section{JURNAL ILMIAH MANAJEMEN dan BISNIS}

respon terhadap objek yang menunjukkan keinginan pelanggan untuk melakukan pembelian. Keputusan untuk membeli dipengaruhi oleh nilai produk yang dievaluasi. Bila manfaat yang dirasakan lebih besar dibandingkan pengorbanan untuk mendapatkannya, maka dorongan untuk membelinya semakin tinggi. Sebaliknya bila manfaatnya lebih kecil dibandingkan pengorbanannya maka biasanya pembeli akan menolak untuk membeli dan pada umumnya beralih mengevaluasi produk lain yang sejenis. Menurut Kotler dan Keller, (2010) minat beli dapat diidentifikasi melalui indikatorindikator sebagai berikut (1) Minat transaksional, yaitu kecenderungan seseorang untuk membeli produk. (2) Minat refrensial, yaitu kecenderungan seseorang untuk mereferensikan produk kepada orang lain. (3) Minat preferensial, yaitu minat yang menggambarkan perilaku seseorang yang memiliki prefrensi utama pada produk tersebut. Preferensi ini hanya dapat diganti jika terjadi sesuatu dengan produk prefrensinya. (4) Minat eksploratif, minan ini menggambarkan perilaku seseorang yang selalu mencari informasi mengenai produk yang diminatinya dan mencari informasi untuk mendukung sifat-sifat positif dari produk tersebut.

Sugiyono, (2010) mengemukakan bahwa, kerangka berfikir merupakan model konseptual tentang bagaimana teori berhubungan dengan berbagai faktor yang telah diidentifikasi sebagai masalah yang penting. Adapun kerangka berfikir dalam penelitian ini adalah sebagai berikut:

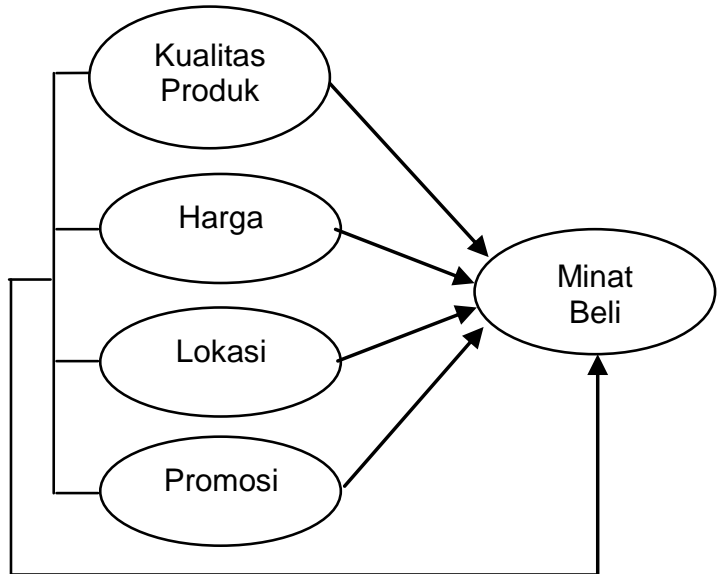

Gambar 1. Kerangka Konseptual

Hipotesis pada penelitian ini adalah H1: Kualitas Produk berpengaruh signifikan secara parsial terhadap Minat Beli konsumen dalam membeli rumah di Kota Batam. H2: Harga berpengaruh signifikan secara parsial terhadap Minat Beli konsumen dalam membeli rumah di Kota Batam. H3: Lokasi berpengaruh signifikan secara parsial terhadap Minat Beli konsumen dalam membeli rumah di Kota Batam. H4: Promosi berpengaruh signifikan secara parsial terhadap Minat Beli konsumen dalam membeli rumah di Kota Batam. H5: Kualitas produk, harga, lokasi dan promosi berpengaruh signifikan secara simultan terhadap Minat Beli konsumen dalam membeli rumah di Kota Batam.

\section{METODE}

Metode penelitian yang digunakan dalam penelitian ini adalah metode penelitian kuantitatif deskriptif yang merupakan penelitian yang digunakan untuk menganalisis data dengan cara mendiskripsikan atau menggambarkan data yang telah terkumpul sebagaimana adanya tanpa bermaksud membuat kesimpulan yang berlaku untuk umum dan generalisasi (Sugiyono, 2010). Lokasi penelitian berada di Kota Batam, dengan menyebarkan kuesioner kepada seluruh masyarakat yang membeli dan memiliki rumah di Kota 


\section{Published April 2018}

\section{JURNAL ILMIAH MANAJEMEN dan BISNIS}

Batam. Populasi pada penelitian ini adalah masyarakat kota Batam dengan jumlah populasi 1.236.399 penduduk. Dalam penelitian ini teknik pengambilan sampel dari suatu populasi, menggunakan teknik Probability Sampling yaitu dengan Simple Random Sampling. Metode penarikan sampel yang dilakukan penulis mengguna kan rumus Slovin (Umar, 2011) dengan tingkat kesalahan (5\%) maka jumlah sampel pada penelitian ini sebesar 399 orang. Teknik pengumpulan data merupakan langkah yang paling strategis dalam penelitian, karena tujuan utama dari penelitian adalah mendapatkan data. Teknik pengumpulan data dapat dilakukan dengan beberapa teknik yaitu interview (wawan cara), kuesioner (angket) dan dokumentasi. Untuk menjawab permasalahan yang dikemukakan dalam penelitian ini, maka beberapa cara yang digunakan adalah Analisis deskriptif yang Dipergunakan untuk menganalisis data yang telah terkumpul sebagaimana adanya tanpa bermaksud membuat kesimpulan yang berlaku untuk umum atau generalisasi. Analisis ini berusaha mengungkapkan fenomena sesuai dengan persepsi responden tentang variabel yang diteliti. Dalam penelitian ini yang digunakan Analisis konfirmatori faktor (Confirmatory Factor Analysis, (CFA)) untuk menguji apakah a) Kualitas Produk, b) Harga, c) Lokasi, d) Promosi, benar-benar merupakan dimensi atau indikator dari faktor minat beli dalam membeli rumah di kota Batam. Untuk mengetahui indikator atau faktor mana yang menetukan keputusan pembelian ditentukan oleh besarnya angka Kaiser-Meyer-Olkin Measure of Sampling Adequacy dari masing-masing indikator tersebut. Suatu indikator dapat dikatakan sebagai pengukur yang siginifikan dari faktor yang diukurnya apabila memiliki nilai Measure of Sampling Adequacy (MSA) lebih besar dari 0,4 atau nilai probabilitas (signifikansi) lebih kecil dari $\alpha=0,05$. Untuk menghasilkan angka dari masing-masing indikator yang diteliti dalam penelitian ini digunakan program SPSS versi 20.

Pengujian Validitas Instrumen dengan melihat Nilai $r_{\text {hitung }}$ dibandingkan dengan nilai $r_{\text {tabel }}$ dengan derajat bebas (n-2). Kaidah yang digunakan dalam uji validitas ini adalah jika $r_{\text {hitung }}>r$ tabel, maka instrumen yang digunakan valid, jika $r_{\text {hitung }}$ $<\mathrm{r}_{\text {tabel}}$, maka /instrumen yang digunakan tidak valid. Apabila nilai koefisien reliabilitas Alfa Cronbach lebih besar dari 0,6 maka instrumen penelitian dianggap reliabel. Nilai yang kurang dari 0,6 dianggap memiliki reliabilitas yang kurang (Wibowo, 2012)

Pengujian normalitas dengan metode Kolmogorov smirnov menggunakan nilai Asymp. Sig. Jika nilai Asymp.Sig lebih besar dari 0,05 maka distribusi data adalah normal. Jika nilai Asymp. Sig lebih kecil dari 0,05 maka distribusi data adalah tidak normal. Sanusi, (2011) menyebutkan bahwa pendeteksian terhadap multikolinearitas dapat dilakukan dengan melihat Variance Inflating Factor (VIF) dari hasil analisis regresi. Jika nilai VIF besar dari 10, maka terdapat gejala multikolinearitas yang tinggi. Uji heteroskedastisitas bertujuan untuk menguji apakah keragaman dari selisih nilai pengamatan dan pendugaan sama untuk semua nilai pendugaan $\mathrm{Y}$. Uji heteroskedastisitas dilakukan dengan metode Glejser dengan cara menyusun regresi antara nilai absolut residual dengan variabel bebas. Apabila masing-masing variabel bebas tidak berpengaruh signifikan terhadap absolut residual $(\alpha=0,05)$ maka dalam model regresi tidak terjadi gejala heteroskedastisitas . Teknik analisa data menggunakan analisis regresi linier berganda.

\section{HASIL}

Penelitian ini dilakukan untuk mengetahui Pengaruh Kualitas Produk, Harga, Lokasi Dan Promosi Terhadap 


\section{JURNAL ILMIAH MANAJEMEN dan BISNIS}

ISSN 1693-7619 (print) | ISSN 2580-4170 (online), http://jurnal.umsu.ac.id/index.php/mbisnis

Minat Beli konsumen dalam membeli dapat dilihat pada Tabel 1 berikut; rumah di Kota Batam. Deskripsi penelitian

Tabel 1. Deskripsi Penelitian

\begin{tabular}{lrrrrrr}
\hline & $\mathrm{N}$ & Minimum & Maximum & Mean & & Std. Deviation \\
\cline { 2 - 7 } & Statistic & Statistic & Statistic & Statistic & Std. Error & Statistic \\
\hline Kualitas Produk & 399 & 19 & 41 & 29,68 &, 214 & 4,271 \\
Harga & 399 & 12 & 30 & 21,30 &, 181 & 3,615 \\
Lokasi & 399 & 7 & 20 & 13,60 &, 137 & 2,737 \\
Promosi & 399 & 10 & 20 & 16,00 &, 106 & 2,120 \\
MinatBeli & 399 & 15 & 30 & 23,55 &, 162 & 3,243 \\
Valid N (listwise) & 199 & & & & & \\
\hline
\end{tabular}

Sumber : Data primer diolah (2017)

Analisis konfirmatori faktor digunakan untuk menguji sebuah konsep yang dibangun dengan menggunakan beberapa indikator terukur. Untuk mengetahui indikator atau faktor mana yang menetukan keputusan pembelian ditentukan oleh besarnya angka Kaiser-Meyer-Olkin Measure of Sampling Adequacy dari masing-masing indikator tersebut. Suatu indikator dapat dikatakan sebagai pengukur yang siginifikan dari faktor yang diukurnya apabila memiliki nilai Measure of Sampling Adequacy (MSA) lebih besar dari 0,4 atau nilai probabilitas (signifikansi) lebih kecil dari $\alpha=0,05$. Adapun hasil dari pada analisis konfirmatori faktor dalam penelitian ini adalah sebagai berikut:

Tabel 2. Hasil Analisis Konfirmatori Faktor

\begin{tabular}{clcccc}
\hline No. & \multicolumn{1}{c}{ Indikator } & Loading faktor & MSA & KMO & Sig \\
\hline 1 & Kualitas Produk (X1) & .711 & .524 & .534 & .002 \\
2 & Harga (X2) & .635 & .621 & & \\
3 & Lokasi (X3) & .922 & .454 & & \\
4 & Promosi & .630 & .580 & & \\
\hline Sumber : Data primer diolah (2017) & & &
\end{tabular}

Berdasarkan hasil analsis dari konfirmatori faktor bahwa Kualitas Produk (X1), Harga (X2), Lokasi (X3) dan Promosi (X4) dalam penelitian ini menujukan berpengaruh positif dan signifikan terhadap Minat Beli (Y) Rumah di kota Batam dengan nilai probabilitas signifikan 0,002 maka ini memenuhi syarat dari nilai signifikan lebih kecil dari $\alpha=0,005$ dengan nilai MSA lebih besar dari 0,4 . Hal ini dapat dilihat pada tabel 4.2 bahwa nilai MSA Kualitas Produk (X1) menujukan angka 0,524, niai MSA Harga (X2) menujukan angka 0,621, nilai MSA Lokasi (X3) menujukan angka 0,454 dan nilai MSA dari Promosi (X4) menujukan angka 0,580. Hal ini dapat diartikan bahwa kualitas produk, harga, lokasi dan promosi dapat dikatakan sebagai faktor yang mempengaruhi minat beli dalam membeli rumah di kota Batam.

Uji normalitas dapat dilakukan dengan menggunakan Histogram Regression Residual yang sudah distandarkan, analisis Chi Square dan juga menggunakan nilai Kolmogorov-Smirnov. Kurva nilai residual terstandarisasi dikatakan normal jika; Nilai kolmogorov-Smirnov $\mathrm{Z}<$ tabel atau menggunakan nilai probability sig (2 tailed) $>\alpha$; sig $>0,05$. Hasil uji normalitas dapat dilihat pada histogram berikut ini : 


\section{JURNAL ILMIAH MANAJEMEN dan BISNIS}

ISSN 1693-7619 (print) | ISSN 2580-4170 (online), http://jurnal.umsu.ac.id/index.php/mbisnis

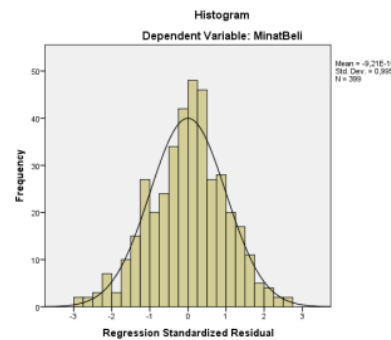

Gambar 4.1. Histogram

Gambar 1, dapat dilihat bahwa data telah terdistribusi secara normal. Hal ini dapat dilihat dari kurva telah berbentuk lonceng. Hasil uji normalitas juga dapat dilihat pada Gambar 2 normal plot berikut:

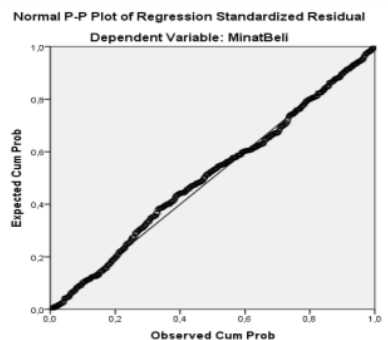

Gambar 4.2. Normal P-lot

Gambar 2, memperlihatkan bahwa data telah terdistribusi scara normal. Hal ini dapat dilihat dari titik-titik menyebar disekitar garis diagonal dan mengikuti garis diagonal. Hasil uji normalitas juga dapat dilihat pada Tabel 3 berikut ini:

Tabel 3. Hasil Uji Normalitas Kolmogorov Smirnov

\begin{tabular}{llr}
\hline & & Unstandardized Residual \\
\hline Normal Parameters & a,b & 399 \\
& Mean & $0 \mathrm{E}-7$ \\
& Std. Deviation & 3,00395955 \\
Most Extreme & Absolute &, 049 \\
Differences & Positive &, 029 \\
Kolmogorov-Smirnov Z & Negative &,- 049 \\
Asymp. Sig. (2-tailed) & &, 982 \\
\hline
\end{tabular}

a. Test distribution is Normal.

b. Calculated from data.

Sumber: Data primer diolah (2017)

Tabel 3, dapat dilihat bahwa data telah terdistribusi secara normal. Hal ini dapat dilihat dari nilai signifikansi kolmogorov smirnov sebesar $0,290>0,05$. Sehingga disimpulkan bahwa data telah terdistribusi secara normal. Hasil uji analisis berganda dapat dilihat pada Tabel 4.

Tabel 4. Analisis Regresi Berganda

\begin{tabular}{llccccc}
\hline \multirow{2}{*}{ Model } & \multicolumn{2}{c}{ Unstandarized Coefficients } & \multicolumn{2}{c}{$\begin{array}{c}\text { Standarized } \\
\text { Coefficients }\end{array}$} & & \\
\cline { 2 - 5 } & \multicolumn{1}{c}{ B } & Std. Error & Beta & t & Sig \\
\hline 1 & (Constant) & 14,053 & 1,597 & & 8,801 &, 000 \\
& KualitasProduk &, 191 & 0,39 &, 124 & 2,350 &, 019 \\
& Harga &, 175 & .048 &, 196 & 3,681 &, 000 \\
& Lokasi &, 147 &, 062 &, 122 & 2,376 &, 018 \\
& Promosi &, 393 &, 074 & 0,257 & 5,314 &, 000 \\
\hline
\end{tabular}

a. Dependent Variable: MinatBeli

Pada Tabel 4, dapat dirumuskan regresi berganda sebagai berikut $\mathrm{Y}=14,053$
$+0,191+0,175+0,147+0,393$, dapat diartikan, Konstanta memiliki nilai sebesar 
14,053. Hal ini berarti, jika kualitas produk, harga, lokasi dan promosi 0, maka minat beli nilainya sebesar 14,053. Koefisien regresi kualitas produk memiliki nilai sebesar 0,191. Hal ini berarti, kualitas produk memiliki pengaruh yang positif terhadap minat beli. Jika kualitas produk naik sebesar $1 \%$ atau 1 satuan, maka nilai minat beli akan naik sebesar 0,191. Koefisien regresi harga memiliki nilai sebesar 0,175. Hal ini berarti, harga memiliki pengaruh yang positif terhadap minat beli. Jika harga naik sebesar $1 \%$ atau 1 satuan, maka nilai minat beli akan naik sebesar 0,175. Koefisien regresi lokasi memiliki nilai sebesar 0,147 . Hal ini berarti, harga memiliki pengaruh yang positif terhadap minat beli. Jika lokasi naik sebesar $1 \%$ atau 1 satuan, maka nilai minat beli akan naik sebesar 0,147 . Koefisien regresi promosi memiliki nilai sebesar 0,393. Hal ini berarti, harga memiliki pengaruh yang positif terhadap minat beli. Jika promosi naik sebesar $1 \%$ atau 1 satuan, maka nilai minat beli akan naik sebesar 0,393.

Hasil uji $t$ pada penelitian ini dapat dilihat pada Tabel 5 berikut:

Tabel 5. Hasil Uji T (Parsial)

Coefficients $^{\mathrm{a}}$

\begin{tabular}{llccccc}
\hline \multirow{2}{*}{ Model } & \multicolumn{2}{c}{ Unstandardized Coefficients } & $\begin{array}{c}\text { Standardized } \\
\text { Coefficients }\end{array}$ & $\mathrm{T}$ & Sig. \\
\cline { 3 - 5 } & \multicolumn{2}{c}{$\mathrm{B}$} & Std. Error & Beta & \\
\hline \multirow{2}{*}{1 (Constant) } & 14,053 & 1,597 & & 8,801 &, 000 \\
& KualitasProduk &, 191 &, 039 &, 124 & 2,350 &, 019 \\
& Harga &, 175 &, 048 &, 196 & 3,681 &, 000 \\
& Lokasi &, 147 &, 062 &, 122 & 2,376 &, 018 \\
& Promosi &, 393 &, 074 &, 257 & 5,314 &, 000 \\
\hline
\end{tabular}

a. Dependent Variable: Minat Beli

Sumber: Data primer diolah (2017)

Tabel 5 dapat disimpulkan, Untuk Hipotesis 1 yang menyatakan bahwa kualitas produk memiliki pengaruh positif dan signifikan terhadap minat beli. Dapat dilihat dari tabel di atas bahwa variabel kualitas produk berpengaruh positif dan signifikan terhadap minat beli. Dikatakan berpengaruh positif karena nilai untuk variabel kualitas produk adalah positif 2,350, karena nilai signifikasi dari variabel kualitas produk sebesar $0,001<$ a 0,05 , dan $\mathrm{t}_{\text {hitung }} 2,350>\mathrm{t}_{\text {tabel }} 1,966$. Hipotesis 2 yang menyatakan bahwa harga memiliki pengaruh positf dan signifikan terhadap minat beli. Dapat dilihat dari tabel di atas bahwa variabel harga berpengaruh positif dan signifikan terhadap minat beli. Dikatakan berpengaruh positif karena nilai untuk variabel harga adalah positif 3,681, karena nilai signifikasi dari variabel harga sebesar $0,000<$ a 0,05 , dan $t_{\text {hitung }} 3,681>$ dari $t_{\text {tabel }} 1,966$. Hipotesis 3 yang menyatakan bahwa lokasi memiliki pengaruh positf dan signifikan terhadap minat beli. Dapat dilihat dari Tabel 5, bahwa variabel lokasi berpengaruh positif dan signifikan terhadap minat beli, dikatakan berpengaruh positif karena nilai untuk variabel lokasi adalah positif 2,376, karena nilai signifikasi dari variabel lokasi sebesar $0,018<$ a 0,05 , dan $t_{\text {hitung }} 3,376>t_{\text {tabel }} 1,966$. Hipotesis 4 yang menyatakan bahwa promosi memiliki pengaruh positif dan signifikan terhadap minat beli. Dapat dilihat dari Tabel 5 bahwa variabel promosi berpengaruh positif dan signifikan terhadap minat beli, dikatakan berpengaruh positif karena nilai untuk variabel promosi adalah 


\section{JURNAL ILMIAH MANAJEMEN dan BISNIS}

positif 5,314. karena nilai signifikasi dari variabel promosi sebesar $0,000<a \quad 0,05$, dan $t_{\text {hitung }} 5,314>t_{\text {tabel }} 1,966$.
Hasil uji F (uji simultan) pada penelitian ini dapat dilihat pada Tabel 6 berikut:

Tabel 6. Hasil Uji F (Simultan)

\begin{tabular}{clccccc}
\multicolumn{8}{c}{ ANOV A $^{\mathbf{a}^{\mathrm{a}}}$} & & & \\
\hline & Model & Sum of Squares & $\mathrm{df}$ & Mean Square & $\mathrm{F}$ & Sig. \\
\hline \multirow{4}{*}{1} & Regression & 634,272 & 4 & 158,568 & 17,597 &, $000^{\circ}$ \\
& Residual & 3550,320 & 394 & 9,011 & & \\
& Total & 4184,591 & 398 & & & \\
\hline
\end{tabular}

a. Dependent Variable: Minat Beli

b. Predictors: (Constant), Promosi, Kualitas Produk, Lokasi, Harga

Sumber: Data primer diolah (2017)

Untuk hipotesis 5 yang menyatakan bahwa kualitas produk, harga, lokasi dan promosi secara bersama-sama memiliki pengaruh terhadap minat beli dapat dilihat dari Tabel 6, bahwa variabel kualitas produk, harga, lokasi dan promosi signifikan terhadap minat beli. Dikatakan signifikan karena nilai signifikasi dari variabel kualitas produk, harga, lokasi dan promosi sebesar 0,000 < nilai a 0,05 dan $F_{\text {hitung }} 35,0991>$ dari nilai $\mathrm{F}_{\text {tabel }} 2,394$.

Hasil analisis koefisien determinasi dapat dilihat pada Tabel 7 berikut:

Tabel 7. Analisis Koefisien Determinasi

\begin{tabular}{|c|c|c|c|c|}
\hline Model & $\mathbf{R}$ & R Square & $\begin{array}{l}\text { Adjusted R } \\
\text { Square }\end{array}$ & $\begin{array}{l}\text { Std. Error of the } \\
\text { Estimate }\end{array}$ \\
\hline 1 & ,389 & ,152 &, 143 & 3,002 \\
\hline
\end{tabular}

Berdasarkan tabel 7, dapat dilihat bahwa nilai $R$ Square $\left(\mathrm{R}^{2}\right)$ sebesar 0,152 . Hal ini berarti minat beli dapat dijelaskan oleh variabel kualitas produk, harga, lokasi dan promosi sebesar $15,2 \%$, sedangkan sisanya sebesar 84,8 dipengaruhi oleh variabel lain yang tidak termasuk dalam penelitian ini.

\section{PEMBAHASAN}

\section{Kualitas produk berpengaruh signifikan terhadap minat beli}

Kualitas produk berpengaruh signifikan terhadap minat beli. Hal ini dapat dilihat dari nilai signifikansi penempatan kerja sebesar 0,031. Nilai signifikansi 0,019< 0,05 , sehingga disimpulkan bahwa hipotesis yang menyatakan bahwa kualitas produk berpengaruh signifikan terhadap minat beli diterima (H1 diterima). Hasil penelitian ini sejalan dengan penelitian (Widyasari dan Fifilia, 2009) yang menyatakan bahwa kualitas poduk berpengaruh signifikan terhadap keputusan pembelian. Senada dengan hasil penelitian (Satria, 2017) yang menunjukkan bahwa Kualitas Produk mempunyai pengaruh yang positif dan signifikan terhadap Minat Beli, dimana Minat Beli yang tinggi dapat dibentuk oleh adanya Kualitas Produk yang meningkat. Begitu juga dengan penelitian (Utami dan Saputra, 2017) yang menyatakan bahwa Kualitas produk berpengaruh signifikan terhadap Minat Beli. Didalam penelitian (Saidani dan Arifin, 2012) secara empiris kualitas produk berpengaruh terhadap minat beli. Demikian juga penelitian (Melnikas, 2014) menyebutkan adanya pengaruh kualitas produk terhadap minat beli. 
Artinya bahwa semakin baik kualitas produk yang ditawarkan oleh perusahaan, maka akan semakin meningkat minat beli konsumen atas produk rumah yang ditawarkan. Pengaruh positif dan signifikan kualitas produk terhadap Minat Beli konsumen menunjukkan bahwa setiap peningkatan kualitas produk yang dihasilkan maka akan mengakibatkan meningkatnya minat beli akan rumah.

\section{Harga berpengaruh signifikan terhadap minat beli.}

Harga berpengaruh signifikan terhadap minat beli. Hal ini dapat dilihat dari nilai signifikansi harga sebesar 0,000. Nilai signifikansi $0,000<0,05$, sehingga disimpulkan bahwa hipotesis yang menyatakan bahwa harga berpengaruh signifikan terhadap minat beli diterima (H2 diterima). Hasil penelitian ini sejalan dengan penelitian (Maoludyo dan Aprianingsih, 2015) yang menyatakan bahwa harga merupakan yag paling berpengaruh signifikan terhadap minat beli. Sejalan juga didalam penelitian (Nasution dan Yasin, 2014) yang menunjukkan harga berpengaruh siginifikan terhadap minat beli perumahan obama Medan. Hasil dari hipotesis ini juga didukung Aptaguna dan Pitaloka, (2016); Satria, (2017); (Tanzila et al., 2015); yang menyebutkan harga sangat mempengaruhi terhadap minat beli. Demiakian juga didalam penelitian (Tamunu dan Tumewu, 2014) menjelaskan kenaikan minat beli dipengaruhi oleh harga. Artinya perubahan harga rumah yang sangat bepengaruh bagi minat beli masyarakat. Oleh sebab itu harga berperan penting dalam minat beli rumah di kota batam. Perubahan harga juga harus didampingi dengan kuliatas produk yang ada.

\section{Lokasi berpengaruh signifikan terhadap minat beli.}

Dari tabel di atas, dapat disimpulkan bahwa lokasi berpengaruh signifikan terhadap minat beli. Hal ini dapat dilihat dari nilai signifikansi lokasi sebesar 0,018. Nilai signifikansi $0,018<0,05$, sehingga disimpulkan bahwa hipotesis yang menyatakan bahwa lokasi berpengaruh signifikan terhadap minat beli diterima ( $\mathrm{H} 3$ diterima). Hasil penelitian ini sejalan dengan penelitian Mahardini dan Woyanti, (2012) yang menyatakan bahwa lokasi berpengaruh signifikan terhadap keputusan pembelian. Begitu juga dalam penelitian Syahputra, (2015); Fahrian et al., (2015); Mahardini dan Woyanti, (2012) yang mengatakan bahwa lokasi berpengaruh terhadap minat beli konsumen.. Hipotesis ini juga didukung didalam penelitian Adam, (2017). Artinya lokasi rumah yang strategis mempengaruhi bagi minat beli dikarenakan jarak yang dekat dengan pusat kota. lokasi berpengaruh positif terhadap minat beli. Hal ini berarti jika lokasi mengalami kenaikan, maka minat beli juga akan naik.

\section{Promosi berpengaruh signifikan terhadap minat beli.}

Promosi berpengaruh signifikan terhadap minat beli. Hal ini dapat dilihat dari nilai signifikansi promosi sebesar 0,000 . Nilai signifikansi $0,000<0,05$, sehingga disimpulkan bahwa hipotesis yang menyatakan bahwa promosi berpengaruh signifikan terhadap minat beli diterima ( $\mathrm{H} 4$ diterima). Hasil penelitian ini sejalan dengan penelitian Nasution dan Yasin, (2014); Mini, (2016); Nguyen, et al., (2015) yang menyatakan bahwa promosi berpengaruh signifikan terhadap minat beli, demikian juga didalam penelitian Anwar, (2011) yang menyatakan minat beli dipengaruhi oleh promosi. Artinya promosi yang sering dilakukan akan menarik minat beli masyarakat untuk membeli rumah. Promosi berpengaruh positif terhadap minat beli. Hal ini berarti jika promosi mengalami kenaikan, maka minat beli juga akan naik. 
Kualitas produk, harga, lokasi dan promosi secara bersama-sama berpengaruh signifikan terhadap minat beli.

Kualitas produk, harga, lokasi dan promosi secara bersama-sama berpengaruh signifikan terhadap minat beli. Hal ini dapat dilihat dari nilai signifikansi sebesar 0,000. Nilai signifikansi $0,000<0,05$, sehingga disimpulkan bahwa hipotesis yang menyatakan bahwa kualitas produk, harga, lokasi dan promosi secara bersama-sama berpengaruh signifikan terhadap minat beli diterima (H5 diterima). Hal ini berarti kualitas produk, harga, lokasi dan promosi dapat dijadikan variabel dalam minat beli konsumen. Hasil penelitian ini juga didukung Brata, et al., (2017) yang menyatakan variabel kualitas produk, harga, lokasi dan promosi berpengaruh secara simultan terhadap minat beli. Demikian juga didalam penelitian Doni \& Soebari, 2012); Hakim, (2016), minat beli secara serentak dipengaruhi oleh kualitas produk, harga, lokasi dan promosi. Demikian juga halnya didalam penelitian

\section{SIMPULAN}

Dari hasil analisis dan pembahasan, dapat disimpulkan sebagai bahwa (1) Kualitas produk berpengaruh signifikan terhadap Minat Beli konsumen; (2) Harga berpengaruh signifikan terhadap minat beli konsumen; (3) Lokasi berpengaruh signifikan terhadap minat beli konsumen; (4) Promosi berpengaruh signifikan terhadap minat beli konsumen; (4) dan kualitas produk, lokasi, harga dan promosi secara bersama-sama berpengaruh signifikan terhadap minat beli konusmen. Dari empat variabel kualitas produk, harga, lokasi dan promosi, variabel promosi adalah variabel yang paling dominan terhadap minat beli rumah di kota batam, aspek ini erat kaitannya dalam seringnya promosi yang dilakukan. Bagi developer, peneliti menyarankan agar menjual produk yang terjangkau oleh masyarakat banyak dan yang sesuai dengan permintan pasar agar meningkatkan minat beli konsumen. Selain itu juga hendaknya developer juga memperhatikan strategi yang menyangkut tentang harga, memberikan kemudahan dalam melakukan pembelian yang dilakukan baik kredit maupun cash serta memberikan tawaran harga yang sangat menarik minat konsumen untuk membeli rumah. Keberadaan lokasi rumah juga perlu mendapat perhatian. Tempat yang strategis, linkungan yang bersih, nyaman dan aman tentu akan sukai oleh konsumen. Untuk lebih mengenalkan produk rumah yang akan ditawarkan kepada masyarakat hendaknya promosi harus dapat dilakukan terus-menerus dan ditingkatkan.

\section{REFERENSI}

Adam, M. (2017). Effect of Price , Design and Location on Decision of Purchase and Its Implication on Customer Satisfaction. International Journal of Economics, Commerce and Management, V(12), 345-353.

Tanzila., Sohail, A, A., \& Tanveer, T. (2015). Buying Behavior of Smartphone among University Students in Pakistan. The International Journal of Business and Management, 3(1), 34-40.

Anwar, Q. (2011). Pengaruh Program Promosi Penjualan Terhadap Minat Beli Harian Kompas Di Surabaya Selatan. Jurnal Pendidikan Tata Niaga, 2(2), 1-20.

Aptaguna, A., \& Pitaloka, E. (2016). Pengaruh Kualitas Layanan Dan Harga Terhadap Minat Beli Jasa Go-Jek. Widyakala, 3(2012), 49-56.

Brata, H. B., Husani, S., \& Ali, H. (2017). The Influence of Quality Products, Price, Promotion, and Location to Product Purchase Decision on Nitchi At PT. Jaya Swarasa Agung in Central Jakarta. Saudi Journal of Business and 


\section{JURNAL ILMIAH MANAJEMEN dan BISNIS

Management Studies, 2(4), 357-374. https://doi.org/10.21276/sjbms

Doni, H., \& Soebari, M. (2012). Pengaruh

Produk, Harga, Promosi Dan Distribusi

Terhadap Keputusan Pembelian

Konsumen Pada Produk Projector

Microvision. Jurnal Ilmu \& Riset Manajemen, 1(8), 1-21.

Hakim, M.M.D.Dzikril H. M. M. (2016).

Pengaruh Kualitas Layanan, Harga,

Lokasi Dan Promosi Terhadap

Keputusan Pembelian. Jurnal Ilmu Dan

Riset Manajemen, 5(11), 1-21.

Eri, Y., Aminul Islam, M., \& Ku Daud, K.

A. (2011). Factors that Influence Customers' Buying Intention on Shopping Online. International Journal of Marketing Studies, 3(1), 128-139. https://doi.org/10.5539/ijms.v3n1p128.

Firdaus, A. (2017). Pengaruh Strategi Pemasaran Terhadap Minat Konsumen Membeli Produk Perumahan (Kasus Pada Perumahan Surya Mandiri Teropong Pt. Efa Artha Utama). Jom Fisip, 4(1), 1-12.

Fahrian, F., Hasiolan, L. B., \& Haryono, A. T. (2015). Pengaruh Citra Merek, Lokasi, Kepercayaan Dan Kualitas Pelayanan Terhadap Minat Membeli Bbm Di Spbu Gasindo Mekar Putra Semarang. Journal of Management, 1(1), 1-19.

Gitosudarmo, I. (2008). Pengantar Bisnis. 2nd ed. Yogyakarta: BPFE Yogyakarta. Kotler, P., \& Armstrong, G. (2008). PrinsipPrinsip Manajemen (12th ed.). Erlangga.

Kotler, P., \& Keller, K. (2009). Manajemen Pemasaran.13th ed.. Jakarta: Erlangga.

Kotler, P., \& Keller, K. (2010). Manajemen Pemasaran. 13th ed. Jakarta: Erlangga.

Lupiyoadi, R. (2013). Manajemen Pemasaran Jasa. 13th ed. Jakarta: Salemba Empat.

Mahardini, I., \& Woyanti, N. (2012). Analisis Pengaruh Harga, Pendapatan, Lokasi, Dan Fasilitas Terhadap
Permintaan Rumah Sederhana (Studi Kasus Perumahan Puri Dinar Mas Semarang), Diponegoro Journal Of Economics, 1(1), 1-11.

Maoludyo, F. T., \& Aprianingsih, A. (2015). Factors Influencing Consumer Buying Intention For Housing Unit In Depok. Journal of Business And Management, 4(4), 484-493.

Melnikas, B. (2014). Influence of Price and Quality to Customer Satisfaction: Neuromarketing Approach, 1(3), 1-2. https://doi.org/10.3846/144.

Mini. (2016). Pengaruh Promosi Dan Brand Trust Terhadap Minat Beli Motor Yamaha ( Studi Pada PT. Serba Mulia Auto ) Di samarinda. eJournal Ilmu Administrasi Bisnis, 4(3), 897-910.

Nguyen, T. N., Phan, T. T. H., \& Vu, P. A. (2015). The Impact of Marketing Mix Elements on Food Buying Behavior: A Study of Supermarket Consumers in Vietnam. International Journal of Business and Management, 10(10), 206-215.

https://doi.org/10.5539/ijbm.v10n10p2 06

Nasution, M. F. R., \& Yasin, H. (2014). Pengaruh Promosi Dan Harga Terhadap Minat Beli Perumahan Obama Pt. Nailah Adi Kurnia Sei Mencirim Medan. Jurnal Manajemen Dan Bisnis, 14(2), 135-143.

Rangkuti, F. (2011). Riset Pemasaran. Jakarta: Gramedia Pustaka Utama.

Saidani, B., \& Arifin, S. (2012). Pengaruh Kualitas Produk Dan Kualitas Layanan Terhadap Kepuasan Konsumen Dan Minat Beli Pada Ranch Market. Jurnal Riset Manajemen Sains Indonesia, 3(1), 1-22.

Sanusi, A. (2011). Metodologi Penelitian Bisnis: Disertai Contoh Proposal Penelitian Bidang Ekonomi Dan Manajemen. Jakarta: Salemba Empat.

Satria, A. A. (2017). Pengaruh Harga, Promosi, dan Kualitas Produk 


\section{Published April 2018 \\ JURNAL ILMIAH MANAJEMEN dan BISNIS \\ ISSN 1693-7619 (print) | ISSN 2580-4170 (online), http://jurnal.umsu.ac.id/index.php/mbisnis}

Terhadap Minat Beli Konsumen Pada

Perusahaan a-36. Jurnal Manajemen

Dan Start-Up Bisnis, 2(1), 45-53.

Sugiyono. (2010). Metode Penelitian

Kuantitatif Kualitatif dan $R \& D$.

Bandung: Alfabeta.

Swastha, B. (2009). Azas-Azas Marketing. Yogyakarta: Liberty.

Syahputra, D. E. (2015). Pengaruh Store Atmosphere , Harga Dan Lokasi

Terhadap Keputusan Pembelian Ore

Premium Store. Journal Ilmu Dan Riset

Manajemen, 4(11), 1-20.

Tamunu, M., \& Tumewu, F. (2014).

Analyzing The Influence Of Price And

Product Quality On Buying Decision

Honda Matic Motorcyles In Manado.

Jurnal EMBA, 2(3), 1255-1263.

Tjiptono, F. (2008). Prinsip-prinsip total quality service. Yogyakarta: Andi.

Umar, H. (2011). Metode Penelitian untuk Skripsi dan Tesis Bisnis. Jakarta: Rajawali Pers.

Utami, R.P., \& Saputra, H. (2017). Pengaruh Harga Dan Kualitas Produk Terhadap Minat Beli Sayuran Organik Di Pasar Sambas Medan. Jurnal Niagawan, 6(2), 1-12.

Wibowo, A. E. (2012). Aplikasi Praktis SPSS Dalam Penelitian. Yogyakarta: Gava Media.

Widyasari, S., \& Fifilia, T. (2009). Analisis Pengaruh Produk, Harga, Promosi Dan Lokasi Terhadap Keputusan Pembelian Rumah ( Studi pada Perumahan Graha Estetika Semarang). Telaah Manajemen, 6(2), 159-169. 